\title{
EFFECT OF SOME VITAMINS AND MICRONUTRIENT DEFICIENCIES ON THE PRODUCTION OF HIGHER ALCOHOLS BY Saccharomyces cerevisiae.
}

\author{
L.E. GUTIERREZ \\ Departamento de Qutmica, ESALQUSP, C.P.9, CEP: 13418-900, Piracicaba, S.P.
}

\begin{abstract}
ARSTRACT: A study was carried out in order to determine the effect of vitamins (biotin, thiamine, pantothenic acid and pyridoxal) and micronutrient (zinc, boron, manganese and iron) deficiencies on higher alcohol production during alcoholic fermentation with the industrially used yeast Saccharomyces cerevisiae $\mathbf{M}-300-\Lambda$. Zinc deficiency induced a reduction on the levels of isobutyl and isoanyl alcohols. An increase on isobutyl alcohol (fivefold) and a reduction of isoamyl alcohol (two fold) and n-propyl alcohol (three fold) contents resulted from pantothenic acid deficiency. whereas pyridoxal deficiency caused an increase on the levels of isobutyl and isoanyl alcohols. Biotin was not essential for the growth of this strain.
\end{abstract}

Key Words: vitamins, Saccharomyces, yeasts, micronutrient, higher alcohols, alcoholic fermentation

\section{EFEITO DA DEFICIÊNCIA DE VITAMINAS E MICRONUTRIENTES SOBRE A PRODUÇÃO DE ÁICOOIS SUPERIORES \\ POR Saccharomyces cerevisiae}

RESUMO: Foi estudado o efeito da deficiência das vitaminas (biotina, tiamina, ácido pantotênico e piridoxal) e de micronutrientes (boro, zinco, manganês e ferro) sobre a produção de álcoois superiores durante a fernentação alcoblica com a levedura industrial Saccharomyces cerevisiae M-300-A. Com a deficiência de zinco ocorreu reduçāo na formação dos álcoois isobutilico e isoamilico enquanto que a deficiência de pantotenato provocou aumento no vível de álcool isobutilico (cerca de cinco vezes) e redução dos álcoois isoamilico (duas vezes) e n-propilico (tres vezes). Na deficiência de piridoxina ocorreu aumento nos teores de isobutilico e de isoamilico. A biotina não foi essencial para 0 crescimento dessa linhagem de levedura.

Descritores: vitaminas, Saccharomyces, levedura, micronutrientes, álcoois superiores, fermentaçāo alcoólica

\section{INTRODUCTION}

Higher alcohols and their esters are important components of the flavour and aroma of alcoholic fermented beverages (SUOMALAINEN, 1971; SUOMALAINEN \& LEHTONEN, 1979). The mixture of higher alcohols, acids and esters, generally referred to as fusel oil, is of considerable importance on the aroma of beers (SIHTO \& ARKIMA, 1963). Isoamyl alcohol (3-methyl-1butanol) constitutes the highest proportion of the alcohol mixture with smaller amounts of n-propyl alcohol (WEBB \& INGRAHAM, 1963).

Higher alcohols are formed as byproducts in alcoholic fermentation carried out by yeasts (WEBB \& INGRAHAM, 1963) and bacteria (BEVERS \& VERACHTERT, 1976) from decarboxylation of ketoacid intermediates in the leucine, isoleucine, valine and threonine biosynthesis (INGRAHAM \& GUYMON, 1960; SUOMALAINEN \& KAHANPAA, 1963; YLANEN, 1966). The addition of these amino acids to a fermentation medium may increase the total formation of the corresponding higher alcohols, although $50 \%$ or more of the fusel alcohols may arise in a beer wort from carbohydrates (SCHULTHESS \& ETTLINGER, 1978).

There are several known factors affecting higher alcohol production by yeasts such as temperature (HOUGH \& STEVENS, 1961), yeast species (FAHRASMANE et al., 1985), aeration (WEBB \& INGRAHAM, 1963), magnesium (NORDSTROM \& CARLSSON, 1965; GILDENHUYS \& SLAUGHTER, 1983) and nitrogen source (AYRAPAA, 1971; BORZANI et al., 1981). The addition of yeast growth inhibitors could also lead to a reduction of higher alcohols as has been shown by NORDSTROM \& CARLSSON 
(1965) for 2,4-dinitrophenol, GUTIERREZ (1988) for sulphite, GUTIERREZ \& ORELLI (1991) for nitrite, GUTIERREZ et al. (1991a) for benzoate and GUTIERREZ et al. (1991b) for acetic acid.

However, it is apparent that little attention has been paid to the effect of micronutrients and vitamin deficiencies on higher alcohol production during ethanolic fermentation. The following study was carried out with the aim of investigating this subject.

\section{MATERIAL AND METHODS}

YEAST. The organism used in this study was Saccharomyces cerevisiae M-300-A, currently in use in Brazil for the production of ethanol.

FERMENTATION MEDIUM. The medium contained per litre: sucrose, $120 \mathrm{~g}$ (micronutrient assay) and $140 \mathrm{~g}$ (vitamin assay); citric acid, $6 \mathrm{~g}$; ammonium sulphate, $1.2 \mathrm{~g} ; \mathrm{KH}_{2} \mathrm{PO}_{4}, 1.5 \mathrm{~g}$; $\mathrm{MgSO}_{4}, 0.75 \mathrm{~g} ; \mathrm{CaCl}_{2} .2 \mathrm{H}_{2} \mathrm{O}, 0.37 \mathrm{~g}$; ergosterol, $0.005 \mathrm{~g}$ and oleic acid, $0.030 \mathrm{~g}$. The following micronutrients were added, per litre: boric acid, $4.7 \mathrm{mg}$; zinc sulphate. $7 \mathrm{H}_{2} \mathrm{O}, 4.7 \mathrm{mg}$; aluminium sulphate. $18 \mathrm{H}_{2} \mathrm{O}, 2.7 \mathrm{mg}$; cupric sulphate, $5 \mathrm{H}_{2} \mathrm{O}$, $1.9 \mathrm{mg}$; manganese sulphate. $\mathrm{H}_{2} \mathrm{O}, 1.3 \mathrm{mg}$; cobalt chloride, $2 \mathrm{H}_{2} \mathrm{O}, 0.4 \mathrm{mg}$; potassium iodide, $0.4 \mathrm{mg}$; ferrous sulphate, $7 \mathrm{H}_{2} \mathrm{O}, 2.3 \mathrm{mg}$. The following vitamins were added, per litre: nicotinic acid, $3 \mathrm{mg}$; biotin, $0.3 \mathrm{mg}$; Ca-D-pantothenic acid, $3 \mathrm{mg}$; thiamine, $3 \mathrm{mg}$; inositol, $15 \mathrm{mg}$ and pyridoxal, $3 \mathrm{mg}$. The $\mathrm{pH}$ was adjusted to 4.0 with $5 \mathrm{~N} \mathrm{KOH}$ and the media sterilized by filtration. The deficient media were obtained by omission of boron, zinc, manganese, and iron salts and thiamine, biotin, pyridoxal and D-pantothenic acid.

FERMENTATION PROCESS. Fermentations were carried out with $250 \mathrm{ml}$ of medium in $500 \mathrm{ml}$ pyrex conical flasks capped with aluminum foil. They were inoculated with $25 \mathrm{mg}$ of yeast (dry matter basis). The flasks were incubated at $33^{\circ} \mathrm{C}$ and carefully shaken every two hours to ressuspend the yeast. When the sugar was completely exhausted the media were analysed for higher alcohols, ethanol and pyruvic acid contents; yeast growth was also determined. The experiments were made in triplicate and repeated twice.

\section{ANALYSIS.}

Ethanol. $25 \mathrm{ml}$ of the centrifuged broth was distilled and $50 \mathrm{ml}$ of the distillate collected in a Kjeldahl modified apparatus. Ethanol was estimated by densimetry according to AMORIM et al. (1979) with an Anton Paar DMA-46 densimeter.

Pyruvic acid. Pyruvic acid was determined according to FRIEDMANN \& HAUGEN (1943).

Higher alcohols. Higher alcohols were analysed by direct injection of 2 microliters of the centrifuged broth in a packed column $(2 \mathrm{~m}$ by 4.8 $\mathrm{mm}$ ) with Hallcomid M-18 (15\% wt). Analyses were performed in a CG-17 Gas Chromatograph provided with a flame ionization detector. The injector and detector temperatures were 180 and $240^{\circ} \mathrm{C}$, respectively, and the column oven operated isothermally at $110^{\circ} \mathrm{C}$. Pure n-propyl, isobutyl and isoamyl alcohols were used as standards. This column does not discriminate isoamyl from active amyl alcohol, so they were both expressed as isoamyl alcohol.

YEAST GROWTH. The yeast concentration was determined gravimetrically after centrifugation followed by washing and drying at $100-105^{\circ} \mathrm{C}$.

\section{RESUIJTS AND DISCUSSION}

TABLE 1 shows the effect of vitamin deficiency on yeast growth and on the ethanol and pyruvic acic production during alcoholic fermentation. A higher reduction on yeast growth was observed in the pantothenic acid deficiency, confirming earlier observations of OLSON \& JOHNSON (1949) and NORDSTROM (1962). A reduction of yeast growth was also observed with thiamine and pyridoxal deficiencies.

The strain used in this study did not show any special requirement for biotin.

Thiamine is essential for pyruvate decarboxylase activity (DIXON \& WEBB, 1964) which could explain the higher excretion of pyruvic acid (TABLE 1) on thiamine deficiency as it has already been pointed out by LAFONLAFOURCADE \& PEYNAUD (1966).

Pantothenic acid is necessary for coenzyme $A$ and acetyl-CoA synthesis (NORDSTROM, 1963) and, therefore, for isoamyl alcohol production (WEBB \& INGRAHAM, 1963). 
TABLE 1 - Effect of vitamin deficiency on yeast growth, ethanol and pyruvic acid production during alcoholic fermentation (each result is the average of six determinations \pm standard error)

\begin{tabular}{lccc}
\hline Treatments & $\begin{array}{c}\text { Yeast growth } \\
\mathrm{mg} / 100 \mathrm{ml}\end{array}$ & $\begin{array}{c}\text { Ethanol } \\
\text { \% volume }\end{array}$ & $\begin{array}{c}\text { Pyruvic acid } \\
\mathrm{mg} / \text { liter }\end{array}$ \\
\hline Complete & $367 \pm 10$ & $8.69 \pm 0,04$ & $136 \pm 12$ \\
- Pantothenic & $300 \pm 23$ & $8.29 \pm 0.04$ & $257 \pm 10$ \\
- Thiamine & $300 \pm 14$ & $8.54 \pm 0.09$ & $474 \pm 13$ \\
- Pyridoxal & $307 \pm 18$ & $8.66 \pm 0.05$ & $236 \pm 15$ \\
- Biotin & $358 \pm 9$ & $8.69 \pm 0.04$ & $136 \pm 11$ \\
\hline \hline
\end{tabular}

TABLE 2 - Effect of vitamin deficiency on higher alcohol production (each result is the average of six determinations \pm standard error) expressed in $\mathrm{mg} /$ litre.

\begin{tabular}{cccc}
\hline Treatments & n-propryl & isobutyl & isoamyl \\
\hline Complete & $20 \pm 2$ & $28 \pm 4$ & $166 \pm 6$ \\
- Pantothenic & $7 \pm 2$ & $151 \pm 9$ & $86 \pm 6$ \\
- Thiamine & $39 \pm 2$ & $140 \pm 6$ & $140 \pm 9$ \\
- Pyridoxal & $18 \pm 2$ & $66 \pm 6$ & $230 \pm 13$ \\
- Biotin & $20 \pm 3$ & $21 \pm 3$ & $162 \pm 5$ \\
\hline \hline
\end{tabular}

This fact could explain the data of TABLE 2 in relation to the reduction of isoamyl alcohol and the increase of isobutyl alcohol when pantothenic acid was deficient in the medium.

The reduction of $n$-propyl alcohol could be due to the reduction of aspartic acid and threonine formation (WEBB \& INGRAHM, 1963). However, NORDSTROM \& CARLSSON (1965) did not observe a reduction of amyl alcohol with pantothenic deficiency. NORDSTROM (1964) has reported that in pantothenic acid deficiency resulted in less yeast growth with lower ethyl acetate and higher acetic acid formation.

Besides the effect on higher alcohols formation with pantothenic deficiency, a hydrogen sulphide odour was observed in the fermented medium as it had already been related by WAINWRIGHT (1962). These data show the role of pantothenic acid in the media for the production of alcoholic beverages.

Although thiamine is necessary for pyruvate decarboxylaseactivity (DIXON \& WEBB, 1964), there was an increase in n-propyl and isobutyl alcohols and a reduction of isoamyl alcohol (TABLE 2). But as this vitamin is also necessary for the synthesis of pantothenic acid (WHITE et al., 1964), this can explain the reduction in isoamyl alcohol content.

GUTIERREZ (1988) related a reduction of higher alcohols content in the presence of sulfite, probably because sulfite causes the destruction of thiamine as shown by BORENSTEIN (1975): 
TABLE 3 - Effect of micronutrient deficiency on yeast growth, ethanol and pyruvic acid production during alcoholic fermentation (Each result is the average of six determinations \pm standard error).

\begin{tabular}{lccc}
\hline Treatments & $\begin{array}{c}\text { Yeast growth } \\
\mathrm{mg} / 100 \mathrm{ml}\end{array}$ & $\begin{array}{c}\text { Ethanol } \\
\% \text { volume }\end{array}$ & $\begin{array}{c}\text { Pyruvic acid } \\
\mathrm{mg} / \text { liter }\end{array}$ \\
\hline Complete & $342 \pm 20$ & $6.65 \pm 0,08$ & $96 \pm 5$ \\
- Boron & $344 \pm 17$ & $6.65 \pm 0.08$ & $93 \pm 6$ \\
- Manganese & $340 \pm 25$ & $6.63 \pm 0.07$ & $96 \pm 10$ \\
- Zinc & $278 \pm 32$ & $6.73 \pm 0.09$ & $96 \pm 8$ \\
- Iron & $331 \pm 20$ & $6.63 \pm 0.07$ & $91 \pm 8$ \\
\hline \hline
\end{tabular}

TABLE 4 - Effect of micronutrient deficiency on higher alcohol ( $\mathrm{mg} /$ litre) production (Each result is the average of six determinations \pm standard error).

\begin{tabular}{lccc}
\hline \hline Treatments & & alcohols & \\
& n-propyl & isobutyl & isoamyl \\
\hline Complete & $17 \pm 3$ & $34 \pm 7$ & $206 \pm 24$ \\
- Boron & $15 \pm 3$ & $32 \pm 4$ & $178 \pm 32$ \\
- Manganese & $15 \pm 2$ & $37 \pm 4$ & $201 \pm 19$ \\
- Zinc & $17 \pm 1$ & $14 \pm 2$ & $80 \pm 9$ \\
- Iron & $15 \pm 2$ & $32 \pm 6$ & $176 \pm 23$ \\
\hline \hline
\end{tabular}

TABLE 2 shows a higher production of isobutyl and isoamyl alcohols in pyridoxal deficiency because this vitamin is essential for transaminase activity (DIXON \& WEBB, 1964) and more ketoacids would be available for decarboxylation and reduction instead of for amino acids synthesis.

In summary, these data show that S.cerevisiae M-300-A requires the vitamins thiamine, pantothenic acid and pyridoxal from exogenous sources and that it does not need biotin for growth and the production of higher alcohols.

It was found that yeast growth was not inhibited when boron, manganese and iron were missing (TABLE 3). These data confirmed the observations with brewers yeast related by NORDSTROM (1964). When no zinc was added to the medium, growth was reduced by $18.7 \%$ and was followed by higher ethanol production. No effect of micronutrients was observed in relation to pyruvic acid formation (TABLE 3). Zinc is essential for several enzymes activities such as ethanolic dehydrogenase, aldolase, alcaline phosphatase (GOTTSCHALK, 1986), DNA and RNA polymerase (AULD et al., 1976), therefore explaining the less amount of biomass formed when zinc was deficient.

The lack of response to iron, boron, and manganese could be due to their presence as impurities in the chemicals used, to an accumulation in the yeast during propagation or even to a lesser need for these micronutrients.

TABLE 4 shows the effect of micronutrient deficiency on higher alcohol production. N-propyl alcohol levels were not 
affected by any deficiency. Of all micronutrients studied only zinc was necessary for higher alcohol production. A significant reduction of isobutyl and isoamyl alcohols was found with zine deficiency. The reduction of yeast growth and higher alcohol production coud be attributed to a lower absorption of sugar, as it has been shown by VISURI \& KIRSOP (1970) or reduction of energetic metabolism (LAWFORD \& PIK, 1980). Also the less amount of isobutyl and isoamyl alcohols may be partly due to a lower activity of ethanolic dehydrogenase which requires zine as a cofactor (GOTTSCHALK, 1986).

\section{ACKNOWLEDGEMENTS}

This work was supported FERMENTECAssessoria em Fermentação Alcoólica (Brasil). The author also likes to thank Dr. Zilmar Ziller Marcos for reading and correcting this manuscript and Mrs. A.V.K.O. Annicchino and Mr. Luis Lucatti for technical assistance.

\section{REFERENCES}

AMORIM, H.V.; ZAGO, E.A.; GUTIERREZ, L.E. Método rápido para o controle da fermentação e destilação. STAB, Açúcar, Álcool e Subprodutos, Piracicaba, v.4, p.31-34, 1979.

AULD, D.S.; ATSUYA, J.; CAMPINO, C.; VALENZUELO, P. Yeast RNA polymerase I: a eukaryotic zinc metalloenzyme. Biochemical and Biophysical Research Communication, New York, v.69, p.548-554, 1976.

AYRAPAA, T. Biosynthetic formation of higher alcohols by yeast. Dependence on the nitrogenous nutrient level of the medium. Joumal of the Institute of Brewing, London, v.77, p.266-276, 1971.

BEVERS, J.; VERACHTERT, H. Synthesis of higher alcohols in the genus Zymomonas. Jounal of the Institute of Brewing, London, v.82, p.35-40, 1976.

BORENSTEIN, B. Stability of nutrients in foods. In: HARRIS, R.S.; KARMAS, E. (Ed). Nutritional evaluation of food processing. Westport: The AVI Publ. 1975, p.16-18.

BORZANI, W.; VAIRO, M.L.R.; KOSHMIZU, L.H.; CRUZ, M.R.M.; PEREGO JR., L. Kinetics of amyl alcohol production during alcohol fermentation of blackstrap molasses. Biomass, London, v.1, p.115126, 1981.
DXXON, M.; WEBB, E.C. Enzymes. 2.ed., New York: Academic Press, 1964. 950p.

FAHRASMANE, C.; JOURET, C.; PARFAIT, A.; GALZY, P. Production of higher alcohols and shorchain fatty acids by different yeasts used in rum fermentations. Journal of Food Science, Champaign, v.50, p.1427-1430, 1985 .

FRIEDMANN, T.E.; HAUgen, G.E. Pyruvic acid. II. The determination of ketoacids in blood and urine. Journal of Biological Chemistry, Baltimore, v.147. p.414-442, 1943.

GILDENHUYS, P.T.; SLAUGHTER, J.C. The metabolism of putrescine, spermidine and spermine by yeast in relation to the availability of magnesium. Journal of the Institute Brewing, London, v.89, p.333-340, 1983.

GOTTSCHALK, G. Bacterial Metabolism. 2.ed., Berlin: Springer-Verlag, 1986.

GUTIERREZ, L.E. Efeito da adição de sulfito sobre a produçao de alcoois superiores durante a fermentação alcoolica. Anais da Escola Superior de Agricultura "Luiz de Queiroz", Piracicaba, v.45, p.359-368, 1988.

GUTIERREZ, L.E.; ORELLI, V.F.M. Efeito do nitrito sobre a fermentação alcoólica realizada por Saccharomyces cerevisiae. Anais da Escola Superior de Agricultura "Luiz de Queiroz", Piracicaba, v.48, n.1, p.41-54, 1991.

GUTIERREZ, L.E.; ANNICCHINO, A.V.K.O; LUCATTI, L.; SILVA, S.B.L. Aumento da produção de etanol a partir de melaço de cana-deaçúcar pela adição de benzoato. Anais da Escola Superior de Agricultura "Luiz de Queiroz", Piracicaba, v.48, n.1, p.1-21, 1991a.

GUTIERREZ, L.E.; ANNICHINO, A.V.K.O; LUCATTI, L.; STIPP, J.M.S. Efeitos do ácido acético sobre a fermentação alcoólica. Arquivo de Biologia Tecnologia, Curitiba, v.34, p.235-242, $1991 b$.

HOUGH, J.S.; STEVENS, R. Beer flavour. IV. Factors affecting the production of fusel oil. Journal of the Institute of Brewing, London, v.67, p.488-494, 1961.

INGRAHAM, J.L.; GUYMON, J.F. The formation of higher aliphatic alcohols by mutant strains of Saccharomyces cerevisiae. Archives of Biochemistry and Biophysics, New York, v.88, p.157-166, 1960. 
LAFON-LAFOURCADE, S.; PEYNAUD, E. Sur les taux des acides cétoniques formés au cours de la fermentation alcoolique. Annales de l'Institute Pasteur, Paris, v.110, p.766-778, 1966.

LAWFORD, H.G.; PIK, J.R. Physiology of Candida utilis yeast in zinc-limited chemostat culture. Canadian Journal of Microbiology, Ottawa, v.26, p.64-70, 1980.

NORDSTROM, K. Formation of ethyl acetate in fermentation with brewer's yeast. III. Participation of coenzyme A. Journal of the Institute of Brewing, London, v.68, p.398-407, 1962.

NORDSTROM, $K$. Formation of ethyl acetate in fermentation with brewer's yeast. IV. Metabolism of acetyl-coenzyme a. Journal of the Institute of Brewing, London, 69: 142-153, 1963.

NORDSTROM, $K$. Formation of ethyl acetate in fermentation with brewer's yeast. V. Effect of some vitamins and mineral nutrients. Joumal of the Institute of Brewing, v.70, p.209-221, 1964.

NORDSTROM, K.; CARLSSON, B.O. Yeast growth and formation of fusel alcohols. Joumal of the Institute of Brewing, London, v.71, p.171-174, 1965.

OLSON, B.H.; JOHNSON, M.J. Factors producing high yeast yields in synthetic media. Joumal of Bacteriology, Baltimore, v.57, p.235-246, 1949.

SCHULTHESS, D.; ETTLINGER, L. Influence of the concentration of branched chain amino acids on the formation of fusel alcohols. Journal of the Institute of Brewing, London. v.84, p.240-243, 1978.

SIHTO, E.; ARKIMA, V. Proportions of some fusel oil components in beer and their effect on aroma. Journal of the Institute of Brewing, London, v.69, p. 20-25, 1963.
SUOMALAINEN, H. Yeast and its effect on the flavour of alcoholic beverages. Journal of the Institute of Brewing, London, v.77, p.164-177, 1971.

SUOMALAINEN, H.; KAHANPAA, H. Formation of fusel alcohols from amino acids with branched chains. Journal of the Institute of Brewing, London, v.69, p.473-478, 1963.

SUOMALAINEN, H.; LEHTONEN, M. The production of aroma compounds by yeast. Journal of the Institute of Brewing, London, v.85, p.149-156, 1979.

VISURI, K.; KIRSOP, B. Influence of $\mathrm{pH}$ and selected cations on the fermentation of maltose and maltotriose. Journal of the Institute of Brewing, London, p.76, p.362-366, 1970.

WAINWRIGHT, T. Hydrogen sulphide formation by pantothenate-deficient yeast. Journal of General Microbiology, London, v.28, p.5, 1962.

WEBB, A.D.; INGRAHAM, J.L. Fusel Oil. Advances in Applied Microbiology, New York, v.5, p.317353, 1963.

WHITE, A.; HANDLER, P.; SMTTH, D.L. Principles of biochemistry. New York: McGraw Hill, 1964.

YLANEN, L. Mutant strains of Saccharomyces yedo producing excesses of fusel alcohols. Journal of the Institute of Brewing, London, v.72, p.50-56, 1966.

Received in May 26, 1993

Accepted in July 30, 1993

Enviado para publicação em 26.05 .93

Aceito para publicação em 30.07 .93 